\title{
Bone alignment after minimally invasive plate osteosynthesis of the tibia in dogs
}

\author{
Jose Sergio Costa Junior ${ }^{*}$ (i) Rafael Manzini Dreibi ${ }^{1}$ (i) Guilherme Galhardo Franco $^{2}$ (D) \\ Luis Gustavo Gosuen Gonçalves Dias ${ }^{1}$ Rogerio Giuffrida ${ }^{3}$ Bid Bruno Watanabe Minto $^{1}$ (D)
}

${ }^{1}$ Departamento de Clínica e Cirurgia Veterinária, Faculdade de Ciências Agrárias e Veterinárias (FCAV), Universidade Estadual Paulista (UNESP), 14884-900, Jaboticabal, SP, Brasil. E-mail: jose.scj@hotmail.com. *Corresponding author.

${ }^{2}$ Departamento de Medicina Veterinária, Centro de Ciências e Engenharia Agronômica, Universidade Federal do Espírito Santo (UFES), Alegre, ES, Brasil.

${ }^{3}$ Departamento de Pós-graduação em Ciência Animal, Universidade do Oeste Paulista (UNOESTE), Presidente Prudente, SP, Brasil.

ABSTRACT: This study assessed radiographically changes in tibial alignment in the frontal and sagittal planes in dogs that underwent minimally invasive plate osteosynthesis (MIPO) without the aid of image intensifiers. Radiographs of dogs with complete non-articular tibial fractures submitted to MIPO were included and evaluated, without the aid of a transoperative image intensifier and / or an association of implants. The tibial mechanical angles ( $m M P T A, m M D T A, m C a P T A$ and $m C r D T A)$ were measured by three evaluators. The data obtained were compared with results from previously published studies. Twenty-seven animals were included in the study. The mean and standard deviation of the angular changes were as follows: $m M P T A, 2.54^{\circ} \pm 3.10\left(-1.1^{\circ}\right.$ to $\left.8.7^{\circ}\right) ; m M D T A, 0.03^{\circ} \pm 0.16\left(-3.44^{\circ}\right.$ to $\left.0.79^{\circ}\right) ; m C a P T A, 37^{\circ} \pm 4.29\left(-6.23^{\circ}\right.$ to $\left.14.87^{\circ}\right)$; and $m C r D T A, 8.25^{\circ} \pm 5.53\left(-0.2^{\circ}\right.$ to $\left.17.28^{\circ}\right)$. There was a negative correlation between " $m C a P T A$ " and " $m C r D T A$ ". MIPO of the tibia without using image intensifiers and implant association can potentially cause angular changes, which can lead to clinically relevant deformities after bone healing.

Key words: angular deformities, mechanical axis, MIPO, fracture.

Avaliação do alinhamento ósseo após osteossíntese minimamente invasiva com placa de tíbia em cães

RESUMO: Este estudo teve como objetivo avaliar radiograficamente as alterações no alinhamento da tíbia nos planos frontal e sagital em cães submetidos à osteossintese minimamente invasiva com placa (MIPO) sem o auxílio de intensificadores de imagem. Foram incluídas e avaliadas radiografias de cães com fraturas completas da tíbia não articulares submetidos a MIPO, sem o auxílio de intensificador de imagem transoperatório elou associação de implantes. Os ângulos mecânicos tibiais (mMPTA, mMDTA, mCaPTA e mCrDTA) foram mensurados por três avaliadores. Os dados obtidos pela média de todas as avaliações foram comparados com resultados de estudos previamente publicados. Vinte e sete animais foram incluidos no estudo. A média e desvio padrão das alterações angulares foram os seguintes: $m M P T A=2,54^{\circ} \pm 3,10\left(-1,1^{\circ}\right.$ a 8, $\left.7^{\circ}\right) ; m M D T A=0,03^{\circ} \pm 0,16\left(-3,44^{\circ}\right.$ a $\left.0,79^{\circ}\right) ; m C a P T A=37^{\circ} \pm 4,29\left(-6,23^{\circ}\right.$ a $\left.14,87^{\circ}\right) ;$ e $m C r D T A=8,25^{\circ} \pm 5,53\left(-0,2^{\circ}\right.$ a $\left.17,28^{\circ}\right)$. Houve uma correlação negativa entre " $m C a P T A$ " e " $m C r D T A$ ". A realização de MIPO em tíbia sem o uso de intensificadores de imagem e associação de implantes pode causar alterações angulares, o que pode levar a deformidades clinicamente relevantes após a cicatrização óssea.

Palavras-chave: deformidades angulares, eixo mecânico, fratura, MIPO.

\section{INTRODUCION}

Improvements in already established fracture fixation techniques and the description of new techniques in veterinary orthopedics have been constantly observed in recent decades, especially those related to the concept of biological osteosynthesis. Using the principle of preservation of the primordial hematoma and soft tissue envelope adjacent to the fractured focus, a reduction in fracture healing time and infection rates have been noted (HUDSON et al.,
2009; LI et al., 2014; XU et al., 2015; ALBERIO et al., 2018).

Minimally invasive plate osteosynthesis (MIPO) represents a large portion of biological osteosynthesis performed in dogs and cats, and excellent results have been reported (SCHMOKEL et al., 2007; GUIOT et al., 2011; BARONCELLI et al., 2012; POZZI et al., 2013). However, despite the indisputable advantages of the MIPO method, some limitations have been discussed recently (ZOU et al., 2013; LI et al., 2017; ROBINSON et al., 2019). In 
addition to the routine complications of conventional osteosynthesis, MIPO has been associated with the potential risk of misalignment (APIVATTHAKAKUL \& CHIEWCHARNTANAKIT, 2009; HUDSON et al., 2009; BUCKLEY et al., 2011). Although, SCHMOKEL et al. (2007) reported only one patient with angular alteration in subjective evaluations among 7 MIPO cases and BARONCELLI et al. (2012) did not report this complication in a comparative study of MIPO and open reduction in 16 dog tibias, it is believed that changes in alignment should be studied in detail. The studies published by APIVATTHAKAKUL \& CHIEWCHARNTANAKIT (2009) and ZOU et al. (2013) showed more relevant rates of deviations, even when using fluoroscopy, which raises the need for a better understanding of this postoperative complication in minimally invasive orthopedic procedures.

Poor bone alignment can lead to significant differences in stress, excessive ligament tension, and erroneous load distribution over the joint. INNOCENTI et al. (2016) showed that $6^{\circ}$ of varusvalgus inclination can generate negative effects on the joint. KOSTUIK et al. (1975) demonstrated that as little as $3^{\circ}$ of tibial varus-valgus inclination is sufficient to unbalance the weight support for the opposite femoral condyle. Long-term joint overload produces negative effects such as cartilage wear, synovitis, and chronic pain (PAGENSTERT et al., 2007).

In view of the need for objective assessments focused on changes in bone alignment of patients treated with MIPO, the present study assessed radiographically changes in the mechanical angles of the tibia in the frontal and sagittal planes of dogs subjected to MIPO, without the aid of image intensifiers. It is hypothetically believed that patients may experience changes in alignment more frequently than has been reported, despite the potential clinical consequences that may be involved.

\section{MATERIALS AND METHODS}

Dogs of both sexes with no weight limit with complete, closed, non-articular fractures of the tibia were included in the study. Dogs that had fractures in other bones or required an association of implants for osteosynthesis were not considered for the study.

All the patients were treated using MIPO, following the guidelines previously described for the technique (HUDSON et al., 2009). Fractures were reduced indirectly without the aid of imageintensifying devices. Hybrid locked stainless steel straight plates (Focus orthopedics, Indaiatuba, São
Paulo, Brazil) available in 2.0-, 2.7-, 3.5-, and 4.5$\mathrm{mm}$ systems, and cortical stainless steel locked screws in 2.0-, 2.7-, and 3.5-mm systems were used. The number of screws and plate size were chosen based on the preoperative planning performed by the attending surgeon. After the final fixation the alignment was subjectively assessed by the surgeon.

Preoperative radiographs of the affected tibia were evaluated in craniocaudal and mediolateral projections to determine the type of fracture (transverse, short oblique, long oblique, or comminuted) and its location (metaphysis or diaphysis). For postoperative radiographs, the caudocranial projection was assumed, which was considered adequate when the medial surface of the calcaneus was aligned at the distal intermediate center of the tibial crest (DISMUKES et al., 2008). Radiographs in the mediolateral projection included the knee and tarsal joint, with $90^{\circ}$ flexion (POZZI et al., 2013).

Radiant Dicom Viewer software (2020.1, Medixant, Poland) was used to perform the radiographic measurements. The radiographs were evaluated by three independent observers. Each evaluator performed three measurements of the same patient. The screw density, plate- bridging ratio, plate length, work length of the plate, and fracture interval were measured as described by MORRIS et al. (2016). All measurements were made in the immediate postoperative period.

In the frontal plane, the reference points established for orientation of the proximal tibia were the most distal aspects of the subchondral bone concavities of the medial and lateral tibial condyles. In the distal portion of the tibia, the most proximal points of the subchondral bone of the two arciform grooves of the tibial cochlea were established. For the mechanical axis of the tibia, the proximal reference point was the most proximal aspect of the intercondylar fossa of the femur and, as a reference of the distal tibia, the most distal point of the subchondral bone of the distal intermediate tibial crest. A line connecting the distal and proximal reference point was made to demonstrate the axis of the tibia, while similarly, two other lines connected the points of proximal and distal orientation of the tibia.

The angle between the tibial mechanical axis and the measurement lines in the near-medial and distal-medial joints determined the aspects of the medial mechanical angle (mMPTA) and the medial mechanical distal tibial angle (mMDTA), respectively. After measuring the angles, they were compared with the normal values previously described (DISMUKES et al., 2007). 
In the sagittal plane, the reference points that formed the proximal orientation line of the tibia were the cranial and caudal aspects of the medial condyle of the tibia. As for the distal tibial orientation line, the reference points were the distal intermediate tibial crest and the caudodistal aspect of the tibial cochlea. Between the points of reference, a line was created connecting the cranial and caudal aspects.

The reference points used to determine the mechanical axis of the tibia in the sagittal plane were the intercondylar eminence and the center of the circle created from the intersection between the distal reference points of the tibia. The angles between the mechanical axis and the joint orientation lines were measured in the caudoproximal and craniodistal aspects, determining the mCaPTA and mCrDTA, respectively. The mCaPTA and $\mathrm{mCrDTA}$ angles were compared with normal values previously described (DISMUKES et al., 2008).

After the mechanical angles of the tibia were determined, the angle of the tibial plateau (TPA $=90^{\circ}-\mathrm{mCaTPA}$ ) was determined (DISMUKES et al., 2008; GUIOT et al., 2011).

\section{Statistical analysis}

Pearson's correlation analysis was used to study the relationship between the continuous variables. For inclusion in the analysis, the average values obtained between evaluators and moments for the variables mMPTA, mMDTA, mCaPTA, and mCrDTA were calculated. The correlation coefficients were estimated by point and interval with $95 \%$ confidence and tested for the hypothesis that they differ statistically from zero. To determine whether continuous variables differed between categories (physical plate, fracture location, involvement of the fibula, and altered values of mMPTA, mMDTA, mCaPTA, and mCrDTA), an unpaired $t$ test was used. To test the association between the categorical variables mentioned above, the chi-square test or Fisher's exact test was used. All the analyses were conducted in the $\mathrm{R}$ program, considering a 5\% level of significance.

\section{RESULTS}

Twenty-seven dogs were included, of which 14 were male and 13 were female $(17$ mixed breed, 2 Rottweilers, 1 English bulldog, 1 bull terrier, 1 American Staffordshire Terrier, 1 Pinscher, 1 Boxer, 1 Shih-tzu, 1 Doberman, and 1 Chowchow). The mean weight was $14.38 \pm 8.81 \mathrm{~kg}(2.736 \mathrm{~kg})$ and age was $4.13 \pm 4.58$ years ( 6 months to 15 years). Among all the dogs evaluated, 14 were considered juvenile because of their open physical plates. Fractures in the diaphyseal region affected 24 animals and metaphase 3 , with $77 \%$ of the total amount showing an associated fibular fracture. The types of fractures were classified as transverse (11.11\%), short oblique (14.81\%), long oblique $(55.55 \%)$, and comminuted $(18.51 \%)$. There was no evidence of limb rotation and deviations in the frontal and sagittal planes on visual assessment during the surgical procedure.

In the frontal radiographic evaluation, the mMPTA variable had 16 animals $(59.25 \%)$ with angles considered normal and $11(40.75 \%)$ outside the normal range. For mMDTA, 22 animals $(81.48 \%)$ were considered normal and only $5(18.52 \%)$ were outside the normal range. In the sagittal plane, all the animals $(100 \%)$ showed a variation in the normality of mCaPTA, whereas only one $(3.7 \%)$ was classified as normal and 26 altered (96.3\%) for the mCrDTA variable. The variables are listed in tables 1 and 2.

The mean and standard deviation of TPA were $22.48^{\circ} \pm 5.53^{\circ}\left(10.93^{\circ}\right.$ to $\left.33.23^{\circ}\right)$. After comparing the angles reported in the present study with the data provided in the literature regarding the normality of tibial angles, the mean and standard deviation of the angular changes were obtained, with $\mathrm{mMPTA}=2.54^{\circ} \pm 3.10\left(-1.1^{\circ}\right.$ at $\left.8.7^{\circ}\right)$, mMDTA $=0.03^{\circ} \pm 0.16\left(-3.44^{\circ}\right.$ to $\left.0.79^{\circ}\right), \mathrm{mCaPTA}=5.37^{\circ}$ $\pm 4.29^{\circ}\left(-6.23^{\circ}\right.$ to $\left.14.87^{\circ}\right)$, and $\mathrm{mCrDTA}=8.25^{\circ} \pm$ $5.53^{\circ}\left(-0.2^{\circ}\right.$ to $\left.17.28^{\circ}\right)$. The changes in the sagittal axis of $\operatorname{dog} 11$ and the change in the mMPTA of $\operatorname{dog}$ 16 are exemplified in figure 1 . The changes in the mechanical angles of each patient as well as the TPA are also listed in table 2 .

The difference in the means of mMPTA of normal and altered animals were statistically significant for the variables "plate-bridging ratio", "work length of the plate", and "physeal plate" (P $<0.05)$. Animals with altered mMPTA had a lower percentage of "plate-bridging ratio" and "work length of the plate", while animals with open "physeal plate" showed greater mMPTA angles.

The association between the variables mMPTA, mMDTA, mCaPTA, and mCrDTA with the variables "screw density", "fracture interval", "plate extension", "fracture location", and "fibula involvement" were not statistically significant $(\mathrm{P}>0.05)$.

The variables "screw density", "fracture interval", "plate bridging ratio", "work length of the plate", "fracture interval", and "plate extension" were correlated with "mMPTA", "mMDTA ", mCaPTA", and "mCrDTA". There was only a negative correlation between "mCaPTA" and "mCrDTA". 
Table 1 - Summary data of 27 dogs with tibial fractures repaired with minimally invasive plate osteosynthesis.

\begin{tabular}{|c|c|c|c|c|c|c|c|c|c|}
\hline Animals & $\mathrm{SD}$ & $\mathrm{FI} \%$ & PBR\% & $\mathrm{PE}$ & WLP\% $\%$ & $\begin{array}{c}\text { mMPTA } \\
\text { mean } \pm \\
\text { standard } \\
\text { deviation }\end{array}$ & $\begin{array}{c}\text { mMDTA } \\
\text { mean } \pm \\
\text { standard } \\
\text { deviation }\end{array}$ & $\begin{array}{c}\text { mCaPTA } \\
\text { mean } \pm \\
\text { standard } \\
\text { deviation }\end{array}$ & $\begin{array}{c}\text { mCrDTA } \\
\text { mean } \pm \\
\text { standard } \\
\text { deviation }\end{array}$ \\
\hline 1 & 0.55 & 29.35 & 94.53 & 3.22 & 49.49 & $94.11 \pm 1.19$ & $94.25 \pm 4.60$ & $61.23 \pm 6.28$ & $88.94 \pm 1.65$ \\
\hline 2 & 0.42 & 17.25 & 96.26 & 5.58 & 59.31 & $96.07 \pm 1.20$ & $92.34 \pm 3.27$ & $65.36 \pm 1.54$ & $90.71 \pm 1.25$ \\
\hline 3 & 0.5 & 35.26 & 79.52 & 2.25 & 47.67 & $91.18 \pm 0.85$ & $95.96 \pm 2.75$ & $74.05 \pm 8.47$ & $82.02 \pm 7.71$ \\
\hline 4 & 0.4 & 6.26 & 70.45 & 11.25 & 48.7 & $99.03 \pm 1.26$ & $94.76 \pm 4.98$ & $72.33 \pm 8.74$ & $89.85 \pm 1.15$ \\
\hline 5 & 0.5 & 30.24 & 85.21 & 2.81 & 51.19 & $98.58 \pm 0.94$ & $92.21 \pm 3.03$ & $60.17 \pm 3.36$ & $92.48 \pm 4.24$ \\
\hline 6 & 0.66 & 20.64 & 74.93 & 3.63 & 51.65 & $90.5 \pm 5.96$ & $94.76 \pm 7.58$ & $68.98 \pm 7.15$ & $92.3 \pm 2.14$ \\
\hline 7 & 0.44 & 36.35 & 84.98 & 2.33 & 53.82 & $95.75 \pm 0.91$ & $92.67 \pm 6.19$ & $65.05 \pm 4.09$ & $93.58 \pm 3.13$ \\
\hline 8 & 0.45 & 26.93 & 92.59 & 3.43 & 60.75 & $98.14 \pm 1.93$ & $95.55 \pm 6.15$ & $74.24 \pm 5.38$ & $97.13 \pm 2.08$ \\
\hline 9 & 0.4 & 20.6 & 70.02 & 3.39 & 45.62 & $98.23 \pm 1.42$ & $100.57 \pm 6.10$ & $61.43 \pm 7.99$ & $88.46 \pm 5.03$ \\
\hline 10 & 0.5 & 21.01 & 77.09 & 3.66 & 45.47 & $104.62 \pm 2.92$ & $91.38 \pm 5.75$ & $79.07 \pm 13.17$ & $90.43 \pm 2.79$ \\
\hline 11 & 0.41 & 31.57 & 94.64 & 2.99 & 61.77 & $91.43 \pm 1.10$ & $95.42 \pm 2.74$ & $56.77 \pm 6.69$ & $97.2 \pm 3.11$ \\
\hline 12 & 0.4 & 27.27 & 79.33 & 2.9 & 52 & $96.42 \pm 1.32$ & $87.15 \pm 2.87$ & $69.52 \pm 3.19$ & $88.87 \pm 5.90$ \\
\hline 13 & 0.41 & 8.17 & 79.11 & 9.72 & 48.52 & $97.35 \pm 1.19$ & $93.63 \pm 5.98$ & $65.26 \pm 10.28$ & $91.5 \pm 4.53$ \\
\hline 14 & 0.41 & 13.07 & 76.96 & 5.88 & 48.8 & $91.97 \pm 1.85$ & $90.12 \pm 1.61$ & $73.23 \pm 8.48$ & $80.8 \pm 7.23$ \\
\hline 15 & 0.5 & 9.78 & 58.09 & 5.9 & 34.19 & $97.11 \pm 0.75$ & $96.66 \pm 5.65$ & $64.64 \pm 6.41$ & $88.27 \pm 3.64$ \\
\hline 16 & 0.57 & 31.6 & 85.82 & 2.7 & 31.68 & $105.56 \pm 2.01$ & $88.75 \pm 2.14$ & $75.78 \pm 11.14$ & $87.9 \pm 1.46$ \\
\hline 17 & 0.44 & 28.99 & 86.6 & 3.01 & 44.02 & $98.02 \pm 1.39$ & $95.5 \pm 3.04$ & $65.85 \pm 10.85$ & $90.34 \pm 3.70$ \\
\hline 18 & 0.41 & 30.35 & 98.08 & 3.23 & 60.59 & $95.08 \pm 1.56$ & $95.92 \pm 2.22$ & $75.91 \pm 8.42$ & $84.95 \pm 2.31$ \\
\hline 19 & 0.36 & 30.25 & 87.4 & 2.88 & 59.68 & $92.65 \pm 1.08$ & $92.46 \pm 3.17$ & $67.45 \pm 6.40$ & $87.26 \pm 4.50$ \\
\hline 20 & 0.41 & 21.9 & 89.17 & 4.07 & 59.98 & $94.55 \pm 1.05$ & $94.37 \pm 4.15$ & $70.08 \pm 6.63$ & $86.63 \pm 4.68$ \\
\hline 21 & 0.36 & 31.72 & 77.95 & 2.45 & 54.6 & $95.07 \pm 0.86$ & $89.8 \pm 5.47$ & $66.2 \pm 7.29$ & $87.1 \pm 3.15$ \\
\hline 22 & 0.55 & 12.7 & 74.46 & 5.85 & 41.21 & $90.56 \pm 1.91$ & $95.37 \pm 4.10$ & $66.63 \pm 19.13$ & $84.78 \pm 2.10$ \\
\hline 23 & 0.45 & 16.92 & 87.8 & 5.1 & 55.31 & $92.56 \pm 0.92$ & $96.12 \pm 4.54$ & $66.5 \pm 4.30$ & $89.96 \pm 1.25$ \\
\hline 24 & 0.41 & 27.6 & 72.13 & 2.61 & 46.22 & $88.64 \pm 9.51$ & $92.01 \pm 5.63$ & $66.52 \pm 7.35$ & $90.38 \pm 4.33$ \\
\hline 25 & 0.41 & 32.04 & 88.69 & 2.76 & 54.98 & $94.45 \pm 0.79$ & $94.76 \pm 3.93$ & $62.4 \pm 2.73$ & $99.58 \pm 5.61$ \\
\hline 26 & 0.41 & 24.74 & 93.95 & 3.79 & 57.93 & $94.37 \pm 0.93$ & $93.13 \pm 2.42$ & $67.98 \pm 4.64$ & $96.45 \pm 2.08$ \\
\hline 27 & 0.44 & 18.35 & 82.02 & 4.46 & 52.46 & $101.04 \pm 1.16$ & $90.11 \pm 1.66$ & $59.94 \pm 5.09$ & $95.83 \pm 2.68$ \\
\hline
\end{tabular}

Abbreviations: SD, screw density; FI, fracture interval; PBR, plate-bridging ratio; PE, plate extension; WLP, work length of the plate; mMPTA, mechanical medial proximal tibial angle; mMDTA, mechanical medial distal tibial angle; mCaPTA, mechanical caudal proximal tibial angle; mCrDA- mechanical cranial distal angle of the tibia.

\section{DISCUSSION}

Biological osteosynthesis has been the center of attention in fracture management in recent years and its benefits are indisputable (ZOU et al., 2013; XU et al., 2015). Relevant success rates have been reported; however, potential complications still exist. Our results allow us to confirm the hypothesis that the treatment of non-articular tibial fractures with the MIPO technique may cause angular alteration, with even higher rates that what has been previously reported.
Since MIPO has the characteristic of maintaining the biological environment through indirect reduction and application of the plate in the bridge mode without manipulating the fracture focus (BARONCELLI et al., 2012), it is understood that there will be greater risks of iatrogenic injury, failures in fixing the implants, and changes in the alignment of the bone axis. However, relatively low rates of these complications have been reported in dogs (SCHMOKEL et al., 2007; GUIOT et al., 2011; BARONCELLI et al., 2012). It is believed 
Table 2 - Summary data of angular deviations in 27 dogs with tibial fractures repaired with minimally invasive plate osteosynthesis (MIPO).

\begin{tabular}{|c|c|c|c|c|c|c|c|c|}
\hline Animals & $\begin{array}{l}\text { Fracture } \\
\text { location }\end{array}$ & $\begin{array}{c}\text { Fracture } \\
\text { classification }\end{array}$ & $\begin{array}{l}\text { Physeal } \\
\text { plate }\end{array}$ & mMPTA & mMDTA & mCaPTA & mCrDTA & TPA \\
\hline 1 & MTS & $\mathrm{SO}$ & closed & $\mathrm{NC}$ & $\mathrm{NC}$ & $-1.77^{\circ}$ & $6.64^{\circ}$ & $28.77^{\circ}$ \\
\hline 2 & metaphysis & comminuted & closed & $\mathrm{NC}$ & $\mathrm{NC}$ & $1.16^{\circ}$ & $8.41^{\circ}$ & $24.64^{\circ}$ \\
\hline 3 & MTS & LO & open & $\mathrm{NC}$ & $\mathrm{NC}$ & $9.85^{\circ}$ & $\mathrm{NC}$ & $15.5^{\circ}$ \\
\hline 4 & MTS & transversal & open & $2.17^{\circ}$ & $\mathrm{NC}$ & $8.13^{\circ}$ & $7.55^{\circ}$ & $17.67^{\circ}$ \\
\hline 5 & MTS & LO & closed & $1.72^{\circ}$ & $\mathrm{NC}$ & $-2.83^{\circ}$ & $10.18^{\circ}$ & $29.83^{\circ}$ \\
\hline 6 & MTS & comminuted & closed & $\mathrm{NC}$ & $\mathrm{NC}$ & $4.78^{\circ}$ & $10^{\circ}$ & $21.02^{\circ}$ \\
\hline 7 & PTS & LO & open & $\mathrm{NC}$ & $\mathrm{NC}$ & $1.3^{\circ}$ & $11.28^{\circ}$ & $24.95^{\circ}$ \\
\hline 8 & MTS & LO & open & $1.28^{\circ}$ & $\mathrm{NC}$ & $10.04^{\circ}$ & $14.83^{\circ}$ & $15.76^{\circ}$ \\
\hline 9 & PTS & LO & open & $1.37^{\circ}$ & $\mathrm{NC}$ & $-1.57^{\circ}$ & $7.46^{\circ}$ & $28.57^{\circ}$ \\
\hline 10 & PTS & SO & open & $7.76^{\circ}$ & $\mathrm{NC}$ & $14.87^{\circ}$ & $8.13^{\circ}$ & $10.93^{\circ}$ \\
\hline 11 & MTS & LO & closed & $\mathrm{NC}$ & $\mathrm{NC}$ & $-6.23^{\circ}$ & $14.9^{\circ}$ & $33.23^{\circ}$ \\
\hline 12 & MTS & LO & open & $\mathrm{NC}$ & $-3.44^{\circ}$ & $5.32^{\circ}$ & $6.57^{\circ}$ & $20.48^{\circ}$ \\
\hline 13 & MTS & transversal & closed & $0.49^{\circ}$ & $\mathrm{NC}$ & $1.06^{\circ}$ & $9.2^{\circ}$ & $24.74^{\circ}$ \\
\hline 14 & metaphysis & comminuted & closed & $\mathrm{NC}$ & $-0.47^{\circ}$ & $9.03^{\circ}$ & $-0.2^{\circ}$ & $16.77^{\circ}$ \\
\hline 15 & PTS & transversal & open & $0.25^{\circ}$ & $\mathrm{NC}$ & $0.44^{\circ}$ & $5.97^{\circ}$ & $25.36^{\circ}$ \\
\hline 16 & PTS & LO & open & $8.7^{\circ}$ & $-1.84^{\circ}$ & $11.58^{\circ}$ & $5.6^{\circ}$ & $14.22^{\circ}$ \\
\hline 17 & MTS & LO & open & $1.16^{\circ}$ & $\mathrm{NC}$ & $1.65^{\circ}$ & $8.04^{\circ}$ & $24.15^{\circ}$ \\
\hline 18 & DTS & SO & closed & $\mathrm{NC}$ & $\mathrm{NC}$ & $11.71^{\circ}$ & $2.65^{\circ}$ & $14.09^{\circ}$ \\
\hline 19 & DTS & $\mathrm{LO}$ & closed & $\mathrm{NC}$ & $\mathrm{NC}$ & $3.25^{\circ}$ & $4.96^{\circ}$ & $22.55^{\circ}$ \\
\hline 20 & PTS & LO & open & $\mathrm{NC}$ & $\mathrm{NC}$ & $5.88^{\circ}$ & $4.33^{\circ}$ & $19.92^{\circ}$ \\
\hline 21 & MTS & LO & open & $\mathrm{NC}$ & $0.79^{\circ}$ & $2^{\circ}$ & $4.8^{\circ}$ & $23.8^{\circ}$ \\
\hline 22 & DTS & SO & closed & $\mathrm{NC}$ & $\mathrm{NC}$ & $2.43^{\circ}$ & $2.48^{\circ}$ & $23.37^{\circ}$ \\
\hline 23 & TMD & comminuted & closed & $\mathrm{NC}$ & $\mathrm{NC}$ & $2.3^{\circ}$ & $7.66^{\circ}$ & $23.5^{\circ}$ \\
\hline 24 & PTS & LO & open & $-1.1^{\circ}$ & $\mathrm{NC}$ & $2.32^{\circ}$ & $8.08^{\circ}$ & $23.48^{\circ}$ \\
\hline 25 & DTS & comminuted & closed & $\mathrm{NC}$ & $\mathrm{NC}$ & $-0.6^{\circ}$ & $17.28^{\circ}$ & $27.6^{\circ}$ \\
\hline 26 & metaphysis & LO & closed & $\mathrm{NC}$ & $\mathrm{NC}$ & $3.78^{\circ}$ & $14.15^{\circ}$ & $22.02^{\circ}$ \\
\hline 27 & MTS & LO & open & $4.18^{\circ}$ & $-0.48^{\circ}$ & $-3.06^{\circ}$ & $13.53^{\circ}$ & $30.06^{\circ}$ \\
\hline
\end{tabular}

Abbreviations: mMPTA, mechanical medial proximal tibial angle ; mMDTA, mechanical medial distal tibial angle; mCaPTA, mechanical caudal proximal tibial angle; mCrDA- mechanical cranial distal angle of the tibia ; TPA, plateau tibial angle; NC, not changed; PTS, proximal third of the shaft; MTS, middle third of the shaft; DTS, distal third of the shaft; SO, short oblique; LO, long oblique.

that the use of transoperative imaging, specialized training of surgeons, over-care for such risks, and implant association such as the intramedullary pin are responsible for the results found and reported so far. Conversely, the technique has spread worldwide and even in more developed regions, the availability of training and fluoroscopy is not common, which means that a large percentage of veterinary surgeons perform MIPO without proper preparation. Conversely, the use of an associated intramedullary pin may be a realistic option for indirect alignment of fractured bone.

Our results showed higher rates of angular changes after surgical correction using the MIPO technique when purchased from others recently performed (GUIOT et al., 2011; BARONCELLI et al., 2012), of which they used the artifice of the transoperative image. However, our deviations were not seen during the subjective evaluation in the transoperative period, which makes us to consider two possibilities: either the deviations were macroscopically imperceptible, or the surgeon was unable to identify them.

MIPO is a challenging technique, requiring time and training to effectively perform it. Surgeons at the beginning of the learning curve may have greater complication rates than more experienced surgeons, such as higher infection rates related or 


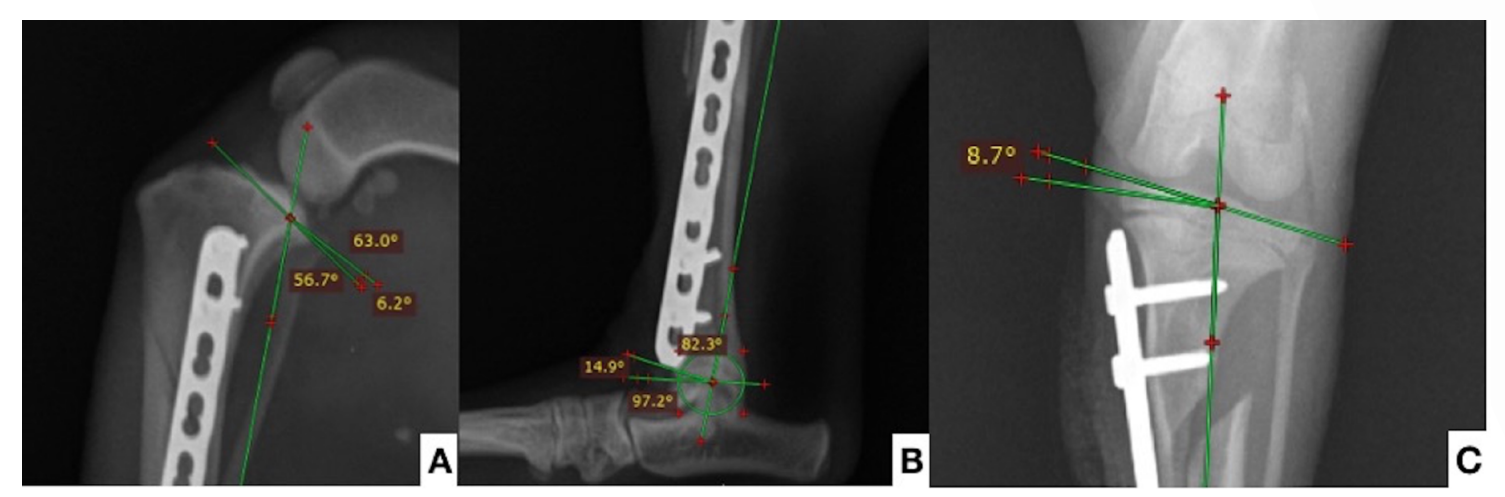

Figure 1 - Medium-lateral radiography (A-B) of dog 11 after measuring the mechanical axis in the sagittal plane. A) By establishing the tibial proximal reference lines, measuring the mCaPTA angle $\left(56.7^{\circ}\right)$ and comparing it with the normal limit $\left(63^{\circ}\right)$, a deviation of $-6.2^{\circ}$ was obtained. B) After establishing the distal tibial reference lines, measuring the mCrDTA angle $\left(97.2^{\circ}\right)$, and comparing it with the normal limit $\left(82.3^{\circ}\right)$, a $14.9^{\circ}$ deviation was obtained. C) Craniocaudal radiography 16. After establishing the tibial proximal reference lines and comparing them with the normal value, a deviation of $8.7^{\circ}$ was obtained.

not to the longer operative time (ROBINSON et al., 2019). Similarly, we believed that the large number of deviations reported may have been caused by the inexperience of the surgeons. However, it is difficult to subjectively measure minor deviations and they may be imperceptible even for experienced surgeons and with the use of intraoperative fluoroscopy. It is worth remembering that the fluoroscope releases large amounts of radiation, which poses a potential risk for the surgery team. The cost and longer surgical time also limit the use of fluoroscopy (MILLER et al., 2010).

In the present study, there was a negative correlation between mCaPTA and $\mathrm{mCrDTA}$; that is, the lower the value of $\mathrm{mCaPTA}$, the greater the value of mCrDTA, but the exact cause of this relationship is not known (DISMUKES et al., 2008). It is suggested that at the point where the proximal and distal fragments move cranially (recurvatum) or caudally (recurvatum), the angles alternate in opposite ways. Another important point was the number of animals with deviations from mCaPTA and mCrDTA, totaling almost $100 \%$ of the animals. Medial surgical access can facilitate the alignment of the angles in the frontal plane; however, the sagittal reference is requested, mainly because the fracture focus is not visible. This may explain the difference in animals affected between the different plans.

Not all the cases had a plate molded on the tibia, which may have triggered the high rates of angular deviations in the present study. This is due to the fact that the tibia has a triangular aspect in the proximal portion, making it difficult to align and affix the plate without proper molding, which was highlighted recently by CABASSU et al. (2019), who obtained good alignment in the frontal plane of the dogs while performing the molding and reduction of the fracture through the bone plate.

The indirect form of reduction associated with the location of the fracture potentially contributes to the formation of the deviations, and depending on its intensity, it causes damage to the underlying joint in the long term. In humans, $10^{\circ}$ of varus deviation and $5^{\circ}$ of valgus deviation in the proximal third of the tibial shaft are sufficient to exert maximum pressure on the medial and lateral articular cartilage of the knee, respectively. In the middle third of the tibial shaft, $15^{\circ}$ of varus or valgus deviations are needed to exert the same pressure on the joint. The more distal the knee joint, the less impact it will have on the articular cartilage (McKELLOP et al., 1991). In our study, 7 dogs presented fractures in the proximal third of the tibia, but none of the animals had varus and valgus alterations greater than 10 degrees and 5 degrees, respectively. However, the largest deviations reported in the frontal plane were of animals affected by fractures in the proximal third of the tibia, dogs 10 and 16 with 7.76 and $8.7^{\circ}$ of Valgus deviation, respectively. Dogs with fractures in the distal third of the tibia had no angular changes in the frontal plane.

Deviations in tibial angles have been described after minimally invasive osteosynthesis (APIVATTHAKAKUL \& CHIEWCHARNTANAKIT, 2009; BUCKEY et al., 2011); however, little is known

Ciência Rural, v.51, n.9, 2021. 
about their long-term effects, which can be potentially harmful. The proximal tibial joint appears to be sensitive to varus and valgus angular deviations (WU et al., 1990). A study by KOSTIUIK et al. (1975) showed that a $3^{\circ}$ lateral tibial deviation regardless of the side causes a change in distribution and transfers the entire load to the opposite condyle. In another study, INNOCENTI et al. (2016) evaluated varus and valgus loads on the knee joint and concluded that varus deviations greater than $6^{\circ}$ and valgus deviations greater than $3^{\circ}$ are already responsible for the damaging effects on the joint. When comparing our results with the data provided in the literature, it is believed that even with the high rates of deviations reported, most would not suffer additional damage in the long run, nor would they need surgical corrections. Only two animals (7.4\%) could have future problems due to the misalignment caused by the MIPO. Future studies are needed to assess the long-term effects of deviations secondary to tibial osteosynthesis by MIPO.

In the frontal plane of the distal region of the tibia, five animals (18.52\%) had altered mechanical angles based on normal values (DISMUKES et al., 2007). However, based on previous studies, these deviations should not be considered clinically relevant (JAEGER et al., 2007; PETAZONNI et al., 2012). JAEGER et al. (2007) considered up to $13^{\circ}$ of distal valgus deformity to be clinically normal. Surgical correction of dogs with more than $16^{\circ}$ valgus deviation in the distal tibial region was reported. In another study, varus deformities of the distal tibia were corrected in animals that had an angular change of more than $20^{\circ}$ (PETAZZONI et al., 2012).

Angular changes in the sagittal plane have been widely discussed. It is known that the measurement of mCaPTA is important to estimate the angle of the tibial plateau (GUIOT et al., 2011; BARONCELLI et al., 2012; MORRIS et al., 2016; CABASSU, 2019) and its increase has been hypothesized in veterinary medicine as a possible risk factor for the development of cruciate ligament failure, causing excessive stress on the cranial cruciate ligament (MORRIS \& LIPOWITZ, 2001). However, not all dogs with high TPA develop cranial cruciate ligament failure (WILKE et al., 2002). SU et al. (2015) demonstrated that the TPA can change according to the breed of the dog, varying from $15.8^{\circ}$ to $40.4^{\circ}$, in which dogs of smaller breeds had a higher average $\left(29.2^{\circ}\right)$ than dogs of larger breeds $\left(26.1^{\circ}\right)$. This same study suggested that the variation in TPA is not related to the rupture of the cranial cruciate ligament. All dogs studied here had abnormal mCaPTA values, which directly interfered with the TPA values. However, the mean APT $\left(22.48^{\circ}\right)$ reportedis in accordance with the normality reported in some studies (MORRIS \& LIPOWITZ, 2001; WILKE et al., 2002) and no dog presented excessive TPA (DUERR et al., 2007). Since the TPA can vary considerably according to the breed and size of the animals (SU et al., 2015), it was not possible to determine whether the changes reported were related to the surgical procedure or the individuality of the patient.

The correlation between the decrease in the ratio of the bridged plate and work area with the increase in patients with deviations in the mMPTA axis, which is associated with the fact that $51 \%$ of the dogs had open (juvenile) physical plate, showed that the technique performed on animals with physical plate open cells is more likely to end mMPTA changes, despite the fact that MIPO is recommended for immature patients (BEALE \& McCALLY, 2012). It is believed that the limitation in extending the plate closer to the joints; which consequently, also favored the reduction of the work area and bridge-bridge ratio, justifing this risk factor.

Considering that a comparison with the contralateral limb was not performed and the mechanical angles of the tibia were compared with data previously published in the veterinary literature, the main limitation of the present study was identified. Another important limitation was the lack of standardization between the period of the fracture until the moment of surgery, which can potentially influence the capacity and quality of indirect fracture reduction.

\section{CONCLUSION}

Tibial MIPO without the use of image intensifiers and the association of implants can potentially result in angular changes, which may represent clinically relevant deformities after bone healing.

\section{ACKNOWLEDGEMENTS}

The authors want to thank the Conselho Nacional de Desenvolvimento Científico e Tecnicológico (CNPq) for the Ph.D's scholarship (PRGS) awarded and financial support provided.

\section{DECLARATION OF CONFLICT OF INTEREST}

The authors declare no conflict of interest. The founding sponsors had no role in the design of the study; in the collection, analysis, or interpretation of data; in the writing of the manuscript, and in the decision to publish the results. 


\section{AUTHORS' CONTRIBUTIONS}

All authors contributed to the development of this research.

\section{REFERENCES}

ALBERIO, R. L. et al. Minimally invasive plate osteosynthesis for proximal humerus fractures: a retrospective study describing principles and advantages of the technique. Adv Orthop, v.2018, p.1-10, 2018. Available from: <https://doi. org/10.1155/2018/5904028>. Accessed: Apr. 10, 2020. doi: $10.1155 / 2018 / 5904028$

APIVATTHAKAKUL, T.; CHIEWCHARNTANAKIT, S Minimally invasive plate osteosynthesis (MIPO) in the treatment of the femoral shaft fracture where intramedullary nailing is not indicated. Int Orthop, v.33, n.4, p.1119-1126, 2009. Available from: <https://doi.org/ 10.1007/s00264-008-0603-2>. Accessed: Apr. 10, 2020. doi: 10.1007/s00264-008-0603-2.

BARONCELLI, A. B. et al. Retrospective comparison between minimally invasive plate osteosynthesis and open plating for tibial fractures in dogs. Vet Comp Orthop Traumatol, v.25, n.5, p.410417, 2012. Available from: $<$ https://doi.org/ 10.3415/VCOT-11-070097>. Accessed: Apr. 10, 2020. doi: 10.3415/VCOT-11-07-0097.

BEALE, B. S. et al. Minimally invasive plate osteossynthesis: tibial and fibula. Vet Clin Small Anim, v.42, n.5, p.1023-1044, 2012. Available from: <https://doi.org/ 10.1016/j.cvsm.2012.08.001>. Accessed: Apr. 10, 2020. doi: 10.1016/j.cvsm.2012.08.001.

BUCKLEY, R. et al. Lower limb malrotation following MIPO technique of distal femoral and proximal tibial fractures. Injury, v.42, n.2, p.194-199, 2011. Available from: <https://doi.org/ 10.1016/j.injury.2010.08.024>. Accessed: Apr. 10, 2020. doi: 10.1016/j.injury.2010.08.024.

CABASSU, J. Minimally invasive plate osteosynthesis using fracture reduction under the plate without intraoperative fluoroscopy to stabilize diaphyseal fractures of the tibia and femur in dogs and cats. Vet Comp Orthop Tramatol, v.32, n.6, p.475482, 2019. Available from: <https://doi.org/ 10.1055/s-00391693413 >. Accessed: Apr. 10, 2020. doi: 10.1055/s-0039-1693413.

DISMUKES, D. I. et al. Radiographic measurement of the proximal and distal mechanical joint angles in the canine tibia. Vet Surg, v.36, n.7, p.699-704, 2007. Available from: <https:// doi.org/ 10.1111/j.1532-950X.2007.00323.x>. Accessed: Apr. 10, 2020. doi: 10.1111/j.1532-950X.2007.00323.x.

DISMUKES, D. I. et al. Radiographic measurement of canine tibial angles in the sagittal plane. Vet Surg, v.37, n.3, p.300305, 2008. Available from: <https://doi.org/ 10.1111/j.1532950X.2008.00381.x>. Accessed: Apr. 10, 2020. doi: 10.1111/j.1532-950X.2008.00381.x

DUERR, F. M. et al. Risk factors for excessive tibial plateau angle in large-breed dogs with cranial cruciate ligament disease. J Am Vet Med Assoc, v.231, n.11, p.1688-1691, 2007. Available from: $<$ https://doi.org/10.2460/javma.231.11.1688>. Accessed: Apr. 10, 2020. doi: 10.2460/javma.231.11.1688.

GUIOT, L. P. et al. Prospective evaluation of minimally invasive plate osteosynthesis in 36 nonarticular tíbial fractures in dogs and cats. Vet Surg, v.40, n.2, p.171-182, 2011. Available from:
$<$ https://10.1111/j.1532-950X.2010.00783.x>. Accessed: Apr. 10, 2020. doi: 10.1111/j.1532-950X.2010.00783.x.

HUDSON, C. C. et al. Minimally invasive plate osteosynthesis: Applications and techniques in dogs and cats. Vet Comp Orthop Traumatol, v.22, n.3, p.175-182, 2009. Available from: $<$ https://10.3415/VCOT-08-06-0050>. Accessed: Apr. 10, 2020. doi: 10.3415/VCOT-08-06-0050.

INNOCENTI, B. et al. Biomechanical Effects of Different Varus and Valgus Alignments in Medial Unicompartmental Knee Arthroplasty. J Arthroplasty, v.31, n.12, p.1-17, 2016. Available from: <https://10.1016/j.arth.2016.07.006>. Accessed: Apr. 10, 2020. doi: 10.1016/j.arth.2016.07.006.

JAEGER, G. H. et al. Morphology and correction of distal tibial valgus deformities. J Small Anim Pract, v.48, n.12, p.678-682, 2007. Available from: $<$ https://10.1111/j.1748-5827.2007.00388.x $>$. Accessed: Apr. 10, 2020. doi: 10.1111/j.1748-5827.2007.00388.x.

KOSTIUIK, J. P. et al. A study of weight transmission through the knee joint with applied varus and valgus loads. Clin Orthop Relat Res, v.108, p.95-98, 1975. Available from: <https:// journals.lww.com/clinorthop/Citation/1975/05000/A_Study_of Weight_Transmission_Through_the_Knee.15.aspx $>$. Accessed: Apr. 10,2020 .

LI, A. et al. Minimally invasive percutaneous plates versus conventional fixation techniques for distal tibial fractures. Int J Surg, v.38, p.52-60, Feb. 2017. Available from: $<$ https://10.1016/j. ijsu.2016.12.028>. Accessed: Apr. 10, 2020. doi: 10.1016/j. ijsu.2016.12.028.

LI, Q. et al. Limited open reduction is better for simple- distal tíbial shaft fractures than minimally invasive plate osteosynthesis. Genet Mol Res, v.13, n.3, p.5361-5368, 2014. Available from: $<$ https://10.4238/2014.July.24.15>. Accessed: Apr. 10, 2020. doi: 10.4238/2014.July.24.15.

McKELLOP, H. A. et al. The effect of simulated fracture-angulations of the tibia an cartilage pressures in the knee joint. J Bone Jt Surg, v.73, n.9, p.1382-1391, 1991. Available from: <https://pubmed. ncbi.nlm.nih.gov/1918121/>. Accessed: Apr. 10, 2020.

MILLER, D. L. et al. Clinical Radiation Management for fluoroscopically guided interventional procedures. Radiology, v.257, n.2, p.321-332, 2010. Available from: <https:// 10.1148/ radiol.10091269>. Accessed: Apr. 10, 2020. doi: 10.1148/ radiol.10091269.

MORRIS, A. P. et al. Plate failure by bending following tibial fracture stabilization in 10 cats. J Small Anim Pract, v.57, n.9, p.472-478, 2016. Available from: <https:// 10.1111/jsap.12532>. Accessed: Apr. 10, 2020. doi: 10.1111/jsap.12532.

MORRIS, E.; LIPOWITZ, A. J. Comparison of tibial plateau angles in dogs with and without cranial cruciate ligament injuries. J Am Vet Med Assoc, v.218, n.3, p.363-366, 2001. Available from: $<$ https://10.2460/javma.2001.218.363>. Accessed: Apr. 10, 2020. doi: $10.2460 /$ javma.2001.218.363.

PAGENSTERT, G. I. et al. Realignment Surgery as Alternative Treatment of Varus and Valgus Ankle Osteoarthritis. Clin Orthop Relat Res, v.462, p.156-168, Sep. 2007. Available from: $<$ https://10.1097/BLO.0b013e318124a462>. Accessed: Apr. 10, 2020. doi: 10.1097/BLO.0b013e318124a462. 
PETAZZONI, M. et al. Treatment of pes varus using locking plate fixation in seven Dachshund dogs. Vet Comp Orthop Traumatol, v.25, n.3, p.231-238, 2012. Available from: <https://10.3415/ VCOT-11-03-0035>. Accessed: Apr. 10, 2020. doi: 10.3415/ VCOT-11-03-0035.

POZZI, A. et al. Retrospective comparison of minimally invasive plate osteosynthesis and open reduction and internal fixation of radius-ulna fractures in dogs. Vet Surg, v.42, n.1, p.19-27, 2013. Available from: <https://10.1111/ j.1532-950X.2012.01009.x>. Accessed: Apr. 10, 2020. doi: 10.1111/j.1532-950X.2012.01009.x.

ROBINSON, W. P. et al. Perceptions of minimally invasive osteosynthesis: A 2018 survey of orthopedic surgeons. Vet Surg, v.48, p.1-8, 2019. Available from: <https://doi.org/10.1111/ vsu.13299>. Accessed: Apr. 10, 2020. doi: 10.1111/vsu.13299.

SCHMOKEL, H. G. et al. Treatment of tíbial fractures with plates using minimally invasive percutaneous osteosynthesis in dogs and cats. J Small Anim Pract, v.48, n.3, p.157:160, 2007. Available from: <https://10.1111/j.1748-5827.2006.00260. $\mathrm{x}>$. Accessed: Apr. 10, 2020. doi: 10.1111/j.17485827.2006.00260.x.

SU, L. et al. Comparison of tibial plateau angles in small and large breed dogs. Can Vet J, v.6, n.6, p.610-614, 2015. Available from:
<https://www.ncbi.nlm.nih.gov/pmc/articles/PMC4431160/>. Accessed: Apr. 10, 2020.

$\mathrm{XU}, \mathrm{H}$. et al. Callus formation and mineralization after fracture with different fixation techniques: minimally invasive plate osteosynthesis versus open reduction internal fixation. PLoS ONE, v.10, n.10, p.1-13, 2015. Available from: $<$ https://doi.org/10.1371/ journal.pone.0140037>. Accessed: Apr. 10, 2020. doi: 10.1371/ journal.pone.0140037.

WILKE, V. L. et al. Comparison of tibial plateau angle between clinically normal Greyhounds and Labrador Retrievers with and without rupture of the cranial cruciate ligament. J Am Vet Med Assoc, v.221, n.10, p.1426-1429, 2002. Available from: <https:// 10.2460/javma.2002.221.1426>. Accessed: Apr. 10, 2020. doi: 10.2460/javma.2002.221.1426.

WU, D.D. et al. Bone and cartilage changes following experimental varus and valgus tibial angulation. J Orthop Res, v.8, n.4, p.572585, 1990. Available from: <https://onlinelibrary.wiley.com/doi/ abs/10.1002/jor.1100080414>. Accessed: Apr. 10, 2020.

ZOU, J. Comparison of minimally invasive percutaneous plate osteosynthesis with open reduction and internal fixation for treatment of extra-articular distal tibia fractures. Injury, v.44, n.8, p.11021106, 2013. Available from: <https:// 10.1016/j.injury.2013.02.006>. Accessed: Apr. 10, 2020. doi: 10.1016/j.injury.2013.02.006. 